\title{
Eksperimentasi Model Pembelajaran Cooperative Script untuk Melatih Kecakapan Akademik Siswa
}

\author{
Linda Herawati $^{*}$ dan Elis Nurhayati ${ }^{2}$ \\ Fakultas Keguruan dan Ilmu Pendidikan, Universitas Siliwangi, Indonesia \\ Jalan Siliwangi No.24, Kahuripan, Tawang, Tasikmalaya, Jawa Barat 46115 \\ 1*Iindaherawati@unsil.ac.id \\ 2elisnurhayati@unsil.ac.id
}

Artikel diterima: 05-12-2018, direvisi: 28-01-2019, diterbitkan: 31-01-2019

\begin{abstract}
Abstrak
Penelitian ini bertujuan untuk mendeskripsikan tentang tingkat kecakapan akademik siswa dengan menerapkan model Pembelajaran Cooperative Scrift dan melihat perbedaan tingkat kecakapan akademik siswa sebelum dan sesudah pembelajaran menggunakan model Cooperative Script. Metode penelitian yang digunakan adalah metode kuantitatif deskriptif karena untuk mendeskripsikan peningkatan siswa dalam kecakapan akademik siswa melalui model pembelajaran Cooperative Script. Sampel dalam penelitian ini adalah siswa kelas VIII.C SMP Negeri 12 Tasikmalaya yang berjumlah 34 orang. Pengumpulan data diambil melalui observasi dan tes. Berdasarkan hasil observasi data bahwa dalam kecakapan akademik siswa sebelum penerapan model pembelajaran Cooperative Script terdapat 15 siswa termasuk kategori kurang dan 19 siswa termasuk kategori sangan kurang, sedangkan setelah pembelajaran Cooperative Script terdapat 10 siswa termasuk kategori sangat tinggi, 21 siswa termasuk kategori tinggi dan 3 siswa termasuk kategori cukup. Dengan skor rata-rata kemampuan kecakapan akademik siswa setelah penerapan model pembelajaran Coopeartive Script adalah 86,73 dan termasuk dalam kategori sangat tinggi. Sehubungan dengan kesimpulan tersebut, maka hendaknya guru berani mencoba menerapkan metode mengajar bervariasi dalam pembalajaran dalam meningkatkan berbagai kemampuan akademik siswa. Kata Kunci: Model Pembelajaran Cooperative Sript, Kecakapan Akademik Siswa.
\end{abstract}

\section{Experimentation of Cooperative Script Learning Models for Students Academic Skills}

\begin{abstract}
This study aims to describe the level of students 'academic skills by applying the Cooperative Scrift Learning model and see the differences in the level of students' academic skills before and after learning using the Cooperative Scrift model. The research method used is descriptive quantitative method because to describe the increase in students in students' academic skills through Cooperative Script learning models. The sample in this study were students of class VIII.C SMP Negeri 12 Tasikmalaya which amounted to 34 people. Data collection is taken through observation and tests. Based on observations of data that in the academic skills of students before the application of the Cooperative Script learning model there were 15 students including the less category and 19 students including the poor category, while after Cooperative Script learning there were 10 students including very high categories, 21 students including the high category and 3 students including enough categories. With the average score of the ability of students' academic skills after the application of the Cooperative Script learning model is 86.73 and is included in the very high category. In connection with these conclusions, teachers should be brave enough to try to apply the varied teaching methods in learning to improve students' various academic abilities.

Keyword: Cooperative Script Learning Model, Student Academics Skills.
\end{abstract}




\section{Pendahuluan}

Pendidikan berorientasi kecakapan hidup bagi peserta didilk adalah sebagai bekal dalam menghadapi dan memecahkan problema hidup dan kehidupan. Baik sebagai pribadi yang mandiri, warga masyarakat, maupun sebagai warga Negara. Menurut Depdiknas (2003) bahwa kecakapan akademik sebagai salah satu aspek dari kecakapan hidup yang secara spesifik diperlukan oleh siapapaun, baik mereka yang bekerja, yang tidak bekerja dan mereka yang sedang menempuh pendidikan. Oleh karena itu kecakapan perlu dikembangkan sejak dini, terutama saat menempuh jenjang pendidikan dasar dan menengah. Kecakapan/kemampuan akademik ini pun diperlukan pada level universitas (Zanthy, 2018).

Kecakapan akademik (Academic skill/AS) sering kali disebut juga kemampuan berpikir ilmiah. Kecakaan pengembangan dari kecakapan rasional yang bersifat umum. Menurut Anwar (2006) mengemukakan bahwa kecakapan akademik mencakup antara lain kecakapan melakukan identifikasi variabel dan menjelaskan hubungannya pada suatu fenomena tertentu (identifying variables and describing relationship among them) merumuskan hipotesis terhadap suatu rangkaian kejadian (constructing hypotheses) serta merancang dan melaksanakan penelitian untuk membuktikan suatu gagasan atau akademik pada dasarnya merupakan

keingintahuan (designing and implementing a research).

Anwar (2006) juga berpendapat bahwa kecakapan akademik sebagai kecakapan hidup yang spesifik penting bagi orangorang yang akan menekuni pekerjaan yang menekankan pada kecakapan berpikir. Kecakapan akademik sudah lebih mengarah kepada kegiatan yang bersifat akademik/keilmuan yang mencakup antara lain kecakapan melakukan identifikasi variabel dan menjelaskan hubunngannya pada suatu fenomena tertentu, merumuskan hipotesis terhadap suatu rangkaian kejadian, serta merancang dan melaksanakan penelitian untuk membuktikan sesuatu gagasan atau keingintahuan.

Pemilihan strategi pembelajaran merupakan salah satu cara dalam memudahkan siswa menerima materi pelajaran. Oleh karena itu, guru dituntut kreatif (Afriansyah, 2017) dan harus memfasilitasi aktivitas siswa dalam mengembangkan kemampuan dengan melibatkan siswa secara aktif. Yaitu dengan memberikan kesempatan kepada siswa untuk bebas berekspresi dalam belajar. Siswa membaca wacana, merangkum materi yang sudah dipelajari, dan bisa menyimpulkan materi dengan mejelaskan kembali materi yang sudah dipelajari.

Menurut Anwar (2006) mengemukakan bahwa kecakapan akademik sering disebut juga dengan kecakapan berpikir ilmiah. Hal ini sependapat dengan penelitian Noor, J dan Noorlaila, bahwa model pembelajaran 
Cooperative Script dapat meningkatkan kemampuan pemecahan masalah peserta didik. Yang artinya model Cooperative Script dapat meningkatkan kecakapan berpikir ilmiah.

Menurut Slavin (2006) karakteristik model pembelajaran Cooperative Sript adalah metode belajar dimana siswa bekerja berpasangan dan bergantian peran sebagai pembaca atau pendengar dalam mengintisarikan bagian-bagian yang dipelajari.

Langkah-langkah

pembelajaran Cooperative Script diambil dari Saudagar dan Idris (2009) adalah sebagai berikut:

a. Guru membagi siswa untuk berpasangan

b. Guru membagikan wacana/materi kepada setiap siswa untuk dibaca dan membuat ringkasan

c. Guru dan siswa menetapkan siapa yang pertama berperan sebagai pembicara dan siapa yang berperan sebagai pendengar.

d. Pembicara membacakan ringkasannya selengkap mungkin dengan memasukkan ide-ide pokok dalam ringkasan, sementara pendengar:

e. Menyimak/mengorak/melengkapi ideide pokok yang kurang lengkap

f. Membantu mengingat/menghafal ideide pokok dengan menghubungkan materi sebelumnya atau dengan materi lain.

g. Bertukar peran, semula berperan sebagai pembicara ditukar menjadi pendengar dan sebaliknya. Kemudian lakukan seperti kegiatan tersebut kembali.

h. Merumuskan kesimpulan bersama siswa dan guru.

i. Penutup.

Model pembelajaran ini lebih memberikan keuntungan kepada siswa karena lebih mengarah kepada terbentuknya kemandirian belajar siswa yang masih dibawah bimbingan dan arahan guru dalam mengerjakan atau menyelesaikan tugas-tugas yang diberikan, namun tetep memberikan kebebasan berekspresi dalam belajar. Sulastri \& Haq (2013) telah meneliti dengan menggunakan model pembelajaran ini, hasilnya pun sesuai dengan hipotesis awal penelitian.

Berdasarkan hal tersebut, maka peneliti melakukan penelitian dengan menggunakan model pembelajaran Cooperative Script untuk mengetahui tingkat kecakapan akademik siswa.

\section{Metode}

Metode penelitan yang digunakan adalah metode kuantitaif deskriptif karena untuk mendeskripsikan peningkatan siswa dalam kecakapan akademik siswa melalui model pembelajaran Cooperative Script. Penelitian ini melibatkan satu kelompok pembelajaran dengan desainnya seperti berikut:

A: $\mathrm{O} \times \mathrm{O}$

Populasinya siswa di SMP Negeri 12 Tasikmalaya dengan sampel penelitiannya seluruh siswa kelas VIIIC yang berjumlah 
34 siswa. Penelitian ini termasuk kedalam penelitian deskriptif yang bertujuan untuk menggambarkan kecakapan Akademik siswa dalam pembelajaran matematika dengan model Cooperative Script.

Tahapan yang dilakukan dalam penelitian ini yaitu tahapan persiapan yang meliputi: membuat instrument tes kecakapan akademik siswa, menguji instrument tes pada siswa yang telah menempuh materi bangun ruang sisi datar; melakukan uji validitas dan reliabilitas soal yang diujicobakan; membuat Rencana Pelaksanaan Pembelajaran (RPP), melengkapi buku ajar dan lembar kerja siswa. Selanjutnya tahap pelaksanaan meliputi: melaksanakan pembelajaran Cooperative Script pada kelas eksperimen dan memberikan tes di awal pembeajaran sebagai hasil observasi dan tes diakhir pembelajaran sebagai posttest untuk mengetahui kecakapan akademik siswa. Kemudian tahap penyelesaian meliputi: mengumpulkan data hasil tes, mengolah dan menganalisis data hasil tes; tahapan terakhir yang dilakukan adalah penarikan kesimpulan.

\section{Hasil dan Pembahasan}

Penelitian ini dilakukan untuk mendeskripsikan kecakapan akademik siswa dengan pembelajaran model Cooperative Script berdasarkan hasil observasi dan tes.

Soal tes tersebut diujicobakan ke kelas IX-C yang sudah menerima materi bangun ruang sisi datar yang berbentuk uraian sebanyak 4 soal. Setelah melaksanakan uji 134 coba, langsung di uji validitas dan reliabilitasnya. Dari keempat soal tersebut menunjukkan bahwa semua soal valid atau layak digunakan untuk penelitian dengan reliabilitasnya menunjukkan kriteria sedang. Setelah soal tes telah menunjukkan dapat dgunakan untuk dilakukan penelitian, peneliti kemudian melaksanakan hasil observasit ke kelas VIII-C yang dilakukan selama $2 \times 45$ menit dilakukan seminggu setelah melaksanakan ujicoba tes tersebut. Pada pertemuan berikutnya peneliti melakukan pembelajaran selama 6 kali pertemuan dengan menggunakan model pembelajaran Cooperative Script yang sesaui dengan RPP dan bahan ajar yang telah dibuat sebelumnya. Setelah selesai semua proses pembelajaran, peneliti melaksanakan postest dalam waktu $2 \times 45$ menit sebanyak 4 soal uraian

Pelaksanan pembelajaran menggunakan model Cooperative Script yang dilaksanakan di SMPN 12 Tasikmalaya dilakukan sebanyak 6 kali pertemuan, ditambah observasi dan tes pada pokok bahasan Kubus dan Balok. Berdasarkan hasil penelitian yang diperoleh untuk Kecakapan Akademik Siswa sebelum pembelajaran dengan model Cooperative Script disajikan dalam tabel 1 berikut:

Tabel 1

Hasil Observasi Kecakapan Akademik Siswa

\begin{tabular}{cccc}
\hline Nilai Akhir & $\begin{array}{c}\text { Jumlah } \\
\text { Siswa }\end{array}$ & $\%$ & Kategori \\
\hline $86-100$ & - & - & Sangat Tinggi \\
\hline $71-85$ & - & - & Tinggi \\
\hline
\end{tabular}

Mosharafa: Jumal Pendidikan Matematika Volume 8, Nomor 1, Januari 2019 Copyright $\odot 2019$ Mosharafa: Jurnal Pendidikan Matematika 


\begin{tabular}{|cccc|}
\hline $56-70$ & - & - & Cukup \\
\hline $41-55$ & 15 & 44,12 & Kurang \\
\hline $0-40$ & 19 & 55,88 & Sangat Kurang \\
\hline Jumlah & 34 & 100 & \\
\hline
\end{tabular}

observasi kecakapan akademik siswa menunjukkan bahwa dalam kategori sangat kurang dengan rata-rata 38.5. Artinya berdasarkan hasil observasi menunjukkan semua siswa masih belum

Dari tabel diatas terlihat bahwa 15 menunjukkan kecakapan akademiknya.

siswa atau 44,12\% dalam tingkat

Untuk tingkat kemunculan tiap kecakapan akademik nya termasuk indikator dalam setiap pertemuan kategori kurang dan 19 siswa atau 55,88\% termasuk kategori sangat kurang dan tidak ada satupun yang termasuk kategori mengalami peningkatan untuk pembelajaran dengan menggunakan model Cooperative Script disajikan pada cukup, tinggi dan sangat tinggi. Hasil tabel 2 berikut:

Tabel 2

Tingkat Kemunculan Indikator Mengidentifikasi Variabel Siswa

\begin{tabular}{|cccccccc}
\hline \multirow{2}{*}{ Indikator } & \multicolumn{4}{c}{ Rata-rata Skor Indikator Pertemuan Ke- } & \multicolumn{2}{c}{ Rata-Rata } \\
\cline { 2 - 8 } & 1 & 2 & 3 & 4 & 5 & 6 & Nilai Akhir \\
\hline Mengidentifikasi Variabel & 71,13 & 73,08 & 79,71 & 82,25 & 86,81 & 88,76 & 80,29 \\
\hline
\end{tabular}

Pada indikator mengidentifikasi ketika harus menyelsaikan sebuah variabel, siswa mengalami peningkatan permasalahan. Akan tetapi pada yang pada tiap pertemuannya. Akan tetapi pertemuan ke-4 samapi dengan pada pertemuan pertama sampai ketiga pertemuan ke-6 mengalami peningkatan tampak dari hasil skor rata-rata pada skor yang cukup signifikan pada indikator indikator mengidentifikasi variabel masih mengidentifikasi variabel. Artinya peserta terdapat beberapa siswa yang lebih didik sudah mulai terbiasa untuk banyak mengalami kesulitan dibandingkan mengidentifikasi terlebih dahulu dalam dengan pertemuan yang lainnya. Hal ini menyelesaikan sebuah permasalahan disebabkan karena siswa masih belum kecakapan akademik. terbiasa mengidentikasi terlebih dahulu

Tabel 3

Tingkat Kemunculan Indikator Menghubungkan Variabel Siswa dalam Pembelajaran dengan Model Cooperative Script

\begin{tabular}{|lccccccc|}
\hline \multirow{2}{*}{ Indikator } & \multicolumn{4}{c}{ Rata-rata Skor Indikator Pertemuan Ke- } & \multicolumn{2}{c}{ Rata-Rata } \\
\cline { 2 - 8 } \multicolumn{1}{c|}{} & 1 & 2 & 3 & 4 & 5 & 6 & Nilai Akhir \\
\hline Menghubungkan Variabel & 78,37 & 81,14 & 82,64 & 89,16 & 91,32 & 95,19 & 86,30 \\
\hline
\end{tabular}


Pada pertemuan pertama berdasarkan skor rata-rata siswa menunjukkan bahwa masih ada yang mengalami kesulitan dibandingkan dengan pertemuan yang lainnya. Akan tetapi indikator menghubungkan variabel, siswa mengalami peningkatan yang pada tiap pertemuannya. Terutama dari pertemuan ke-3 dengan pertemuan ke-4 mengalami peningkatan skor yang cukup signifikan pada indikator mengidentifikasi variabel. Artinya peserta didik dari awal pertemuan sudah terbiasa dalam menghubungkan variabel ketika menyelesaikan permasalahan kecakapan akademik.

Tabel 4

Tingkat Kemunculan Indikator Merumuskan Hipotesis Siswa dalam Pembelajaran dengan Model Cooperative Script

\begin{tabular}{|lccccccc|}
\hline \multicolumn{1}{c}{ Indikator } & \multicolumn{4}{c}{ Rata-rata Skor Indikator Pertemuan Ke- } & \multicolumn{2}{c}{ Rata-Rata } \\
\cline { 2 - 8 } \multicolumn{1}{c|}{} & 1 & 2 & 3 & 4 & 5 & 6 & Nilai Akhir \\
\hline Merumuskan Hipotesis & 75,64 & 79,17 & 80,12 & 83,35 & 86,73 & 89,67 & 82,45 \\
\hline
\end{tabular}

Pada indikator merumuskan hipotesis, berdasarkan skor rata-rata siswa pada pertemuan pertama dan kedua masih tampak yang mengalami kesulitan dalam merumuskan hipotesis dibandingkan pertemuan yang lainnya. Karena siswa jarang melakukan hipotesis terlebih dahulu. Yang biasa dilakukan siswa

langung mencari solusi dari permasalahan tersebut. Pada perrtemuan ketiga dan seterusnya pada siswa mengalami peningkatan yang pada tiap pertemuannya yang cukup signifikan. Artinya peserta didik sudah mampu melakukan hipotesis terlebih dahulu ketika harus mencari solusinya.

Tabel 5

Tingkat Kemunculan Indikator Melaksanakan Penyelidikan Siswa dalam Pembelajaran dengan Model Cooperative Script

\begin{tabular}{|lcccccccc}
\hline \multirow{1}{*}{ Indikator } & \multicolumn{4}{c}{ Rata-rata Skor Indikator Pertemuan Ke- } & \multicolumn{2}{c}{ Rata-Rata } \\
\cline { 2 - 8 } & 1 & 2 & 3 & 4 & 5 & 6 & Nilai Akhir \\
\hline Melaksanakan Penelitian/Penyelidikan & 69,25 & 74,33 & 76,12 & 81,08 & 82,21 & 85,73 & 78,12 \\
\hline
\end{tabular}

Pada indikator melaksanakan skor rata-rata yang diperoleh siswa penyelidikan, siswa banyak mengalami mencapai 69,75. Akan tetapi mulai kesulitan pada pertemuan pertama sampai pertemuan keempat tiap pertemuannya pertemuan ketiga. Hal ini disebabkan mengalami peningkatan dimana siswa dalam siswa tidak terbiasa melakukan penyelidikan setelah melakukan sudah mulai terbiasa dalam melaksanakan penyelidikan. Berdasarkan hasil perhitungan atau penyelesaian sebuah penelitian, menunjukkan nilai dari tiap permasalahan matematika. Berdasarkan indikatornya tidak terlalu berbeda jauh. 
Berdasarkan hasil observasi pada tabel 2 menyatakan bahwa rata-rata skor untuk kecakapan akademik siswa adalah 81,79. Sehingga dengan nilai tersebut dapat dinyatakan bahwa kecakapan akademik siswa termasuk kategori tinggi.

Berdasarkan rata-rata skor tingkat kemunculan tiap indikator menunjukkan siswa masih mengalami kesulitan dalam melaksanakan penyelidikan karena mereka jarang melakukan hal tersebut ketika melakukan penyelesaian sebuah permasalahan.

Tabel 6

Rata-Rata Skor Tingkat Kemunculan Tiap Indikator Kecakapan Akademik Siswa dalam Pembelajaran dengan Model Cooperative Script

\begin{tabular}{lc|}
\hline \multicolumn{1}{c}{ Indikator } & Nilai Akhir \\
\hline $\begin{array}{l}\text { Mengidentifikasi } \\
\text { Variabel }\end{array}$ & 80,29 \\
\hline $\begin{array}{l}\text { Menghubungkan } \\
\text { Variabel }\end{array}$ & 86,30 \\
\hline Merumuskan Hipotesis & 82,45 \\
\hline $\begin{array}{l}\text { Melaksanakan } \\
\text { Penelitian/ } \\
\text { Penyelidikan }\end{array}$ & 78,12 \\
\hline \multicolumn{1}{c}{ Rata-Rata Nilai Akhir } & 81,79 \\
\hline
\end{tabular}

Pembelajaran dilakukan sebanyak 6 kali pertemuan, tiap pertemuan setiap siswa mengerjakan soal latihan dan diberikan tes. Dalam setiap pertemuan tersebut nampak perbedaan kecakapan akademik yang cukup signikan setelah menggunakan model pembelajaran Cooperative Script

Untuk tes akhir dilakukan pada pertemuan ke delapan. Tes dilakukan secara individu untuk mengetahui penugasaan siswa terhadap materi yang diajarkan. Ketika melakukan postes peneliti juga melakuakn observasi perilaku siswa ketika mengerjakan. Hasil tes individu yang diperoleh disajikan pada tabel berikut:

Tabel 7

Hasil Tes Kecakapan Akademik

\begin{tabular}{|cccc|}
\hline $\begin{array}{c}\text { Nilai } \\
\text { Akhir }\end{array}$ & $\begin{array}{c}\text { Jumlah } \\
\text { Siswa }\end{array}$ & $\%$ & Kategori \\
\hline $86-100$ & 10 & 29,42 & Sangat Tinggi \\
\hline $71-85$ & 21 & 61,76 & Tinggi \\
\hline $56-70$ & 3 & 8,82 & Cukup \\
\hline $41-55$ & - & - & Kurang \\
\hline $0-40$ & - & - & Sangat Kurang \\
\hline Jumlah & 34 & 100 & \\
\hline
\end{tabular}

Dari tabel tersebut terdapat 10 siswa atau 29,42\% termasuk kategori sangat tinggi, 21 siswa atau 61,76\% termasuk kategori tinggi dan 3 siswa atau 8,82\% termasuk kategori cukup.

Berdasarkan hasil tersebut dan haasil observasi menunjukkan bahwa peserta didik sudah mengalami perubahan kecakapan akademik uang cukup signifikan dibandingkan dengan hasil observasi. Dari analisis hasil belajar diperoleh rata-rata akhir yaitu 82,73. Hal tersebut dapat dinyatakan bahwa kecakapan akademik siswa dengan pembelajaran model Cooperative Script termasuk kategori tinggi. Artinya kecakapan akademik siswa termasuk kategori tinggi, tidak terlepas dari bahwa pembelajaran dengan model Cooperative Script memiliki peran yang lebih baik terhadap kecakapan akademik siswa. 
Dalam penelitian ini pelaksanaan pembelajaran model Cooperative Script adalah pembelajaran yang menekankan pada kerjasama secara berkelompok kemudian kelompok tersebut bergantian secara lisan mengintisarikan materi-materi yang dipelajari. Bahwa dalam pembelajaran ini diharuskan ada kesepakatan tentang aturan-aturan dalam berkolaborasi sehingga masalah dapat diselesaikan bersama. Berikut proses pembelajaran dengan Cooperative Script:

Pada pertemuan pertama dengan pembelajaran model Cooperative Script siswa merasa kebingungan, dikarenakan siswa belum terbiasa dengan model pembelajaran yang diberikan. Pada pembelajaran pertama siswa masih banyak yang berbicara diluar pembahasan materi yang ada. Tetapi siswa mulai terbiasa dengan model pembelajaran Cooperative Script pada pertemuan ketiga. Karena pada setelah pertemuan kesatu dan diaawal pertemuan kedua siswa diberikan motivasi manfaat pembelajaran dengan model Cooperative Script.

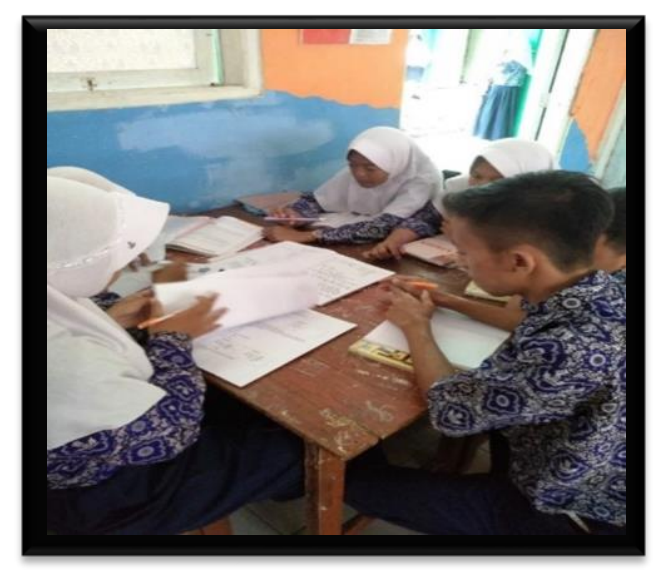

Gambar 1. Ketika siswa membaca dan membuat ringkasan.
Pada pertemuan pertama pada tahap siswa membaca dan membuat ringkasan, masih banyak siswa yang tidak membaca dengan seksama dari permasalah yang diberikan. Dalam satu kelompok hanya satu orang yang membaca permasalahan tersebut, sisanya diam tidak melakukan apa-apa. Dikarenakan siswa sudah terbiasa dengan model pembelajaran yang tanpa melakukan diskusi, artinya lebiyh mengerjakan secara individual dan hanya memperhatikan apa yang disampaikan oleh guru saja.

Langkah berikutnya menetapkan siapa yang pertama berperan sebagai pembicara dan siapa yang berperan sebagai pendengar. Pada pertemuan pertama proses pemilihan ini cukup lama, karena banyak siswa yang tidak mau melakukannya, karena mereka tidak terbiasa untuk tampil didepan kelas dan menyampaikan pendapat ke teman yang lain.

Akan tetapi pada pertemuan berikutnya sudah terbiuasa dan tidak terlalu susah. Akan tetapi berlomba-lomba ingin tampil didepan karena ssudah diberi mortivasi terlebih dahulu.

Tahap berikutnya, tugas pembicara membacakan ringkasannya selengkap mungkin dengan memasukkan ide-ide pokok dalam ringkasan, sementara pendengar. Pada tahap ini siswa masih kesulitan ketika harus membuat ringkasan. Karena siswa masih belum paham dari permasalahan yang diajukan. 


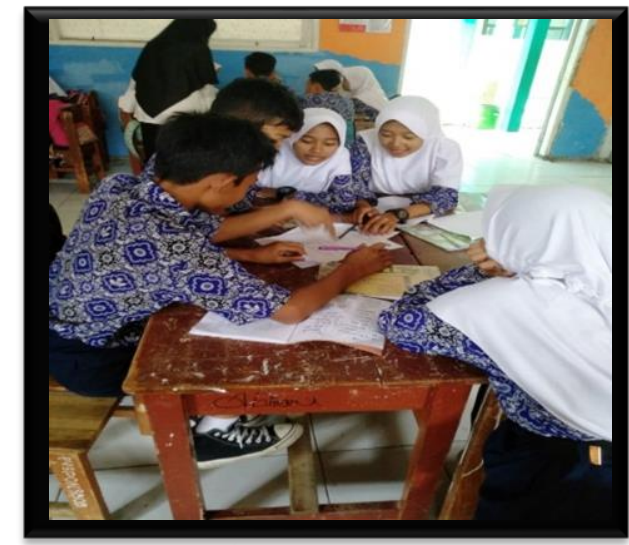

Gambar 2. Ketika siswa melengkapi ide-ide yang kurang.

Anggota kelompoknya bertugas menyimak/ melengkapi ide-ide pokok yang kurang lengkap apa yang disampaikan oleh pembicara. Pada tahap ini pada pertemuan pertama banyak siswa yang tidak memperhatikan apa yang disampaikan oleh pembicara, akan tetapi lebih berbicara dengan teman yang lain. Setelah dilakukan pendekatan oleh peneliti pada pertemuan berikutnya anggota kelompok sudah lebih banyak memperhatikan pembicara.

Proses yang lumayan cukup lama yaitu ketika peneliti harus membantu mengingat/ menghafal ide-ide pokok dengan menghubungkan materi sebelumnya atau dengan materi lain. Karena siswa terkadang mengabaikan atau lupa materi sebelumnya yang berkaitan dengan perm,asalah tersebut. sehingga peneliti harus mengingatkan kembali materi yang terkait dengan permasalah tersebut. Hal ini terjadi pada pertemuan pertama sampai pertemuan ketiga. Pada pertemuan keempat sudah tidak banyak lagi yang harus dibantu dalam mengingat keterkaitan materi sebelumnya.

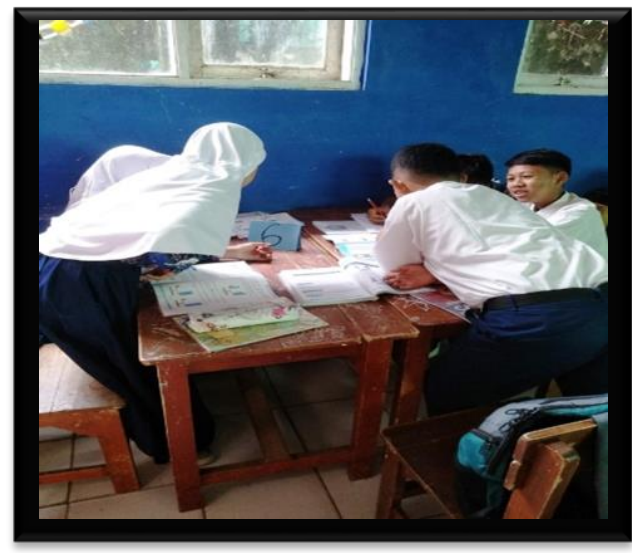

Gambar 3. Ketika siswa bertukar peran.

Langkah berikutnya yang dilakukan siswa yaitu setiap kelompok bertukar peran, semula berperan sebagai pembicara ditukar menjadi pendengar dan sebaliknya. Kemudian lakukan seperti kegiatan tersebut kembali. Pada pertemuan pertama dan kedua terjadi kegaduhan. Dan proses yang dilakukan cukup lama seperti pertama kalli harus menentukan pembicara.

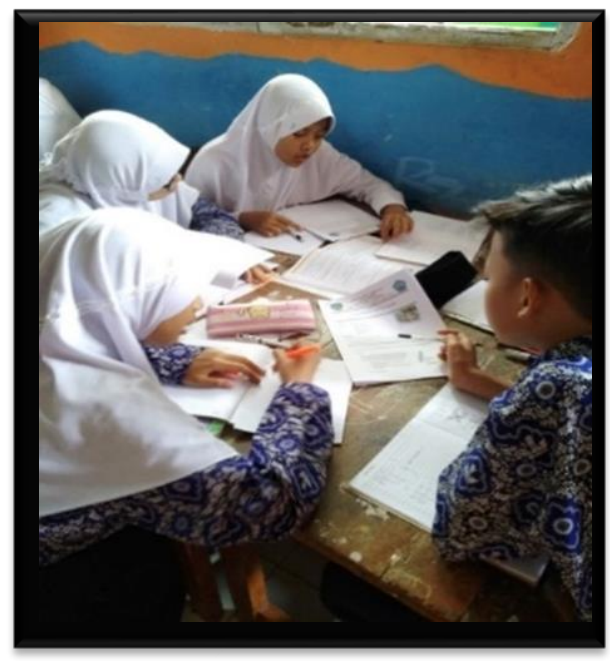

Gambar 4. Siswa sedang melakukan diskusi kelompok secara berpasangan. 
Setelah siswa melakukan pembelajaran secara berpasangan dan bergantian peran dari tiap kelompok mempresentasikan kedepan kelas. Ketika mempresentasikan pada pertemuan pertama siswa lebih banyak diam tanpa memberikan masukan dan tidak memperhatikan apa yang disampaikan temannya di depan kelas. Ketika berlangsungnya diskusi peneliti tetap harus terus membertikan dorongan untuk memperhatikan dan memberikan pendapat mereka kepada temannya. Pada pertemuan ketiga, siswa sudah mulai berlomba lomba untuk memberikan sanggahan atau pendapat. Berikut gambar ketika siswa mempresentasikan hasil diskusinya.

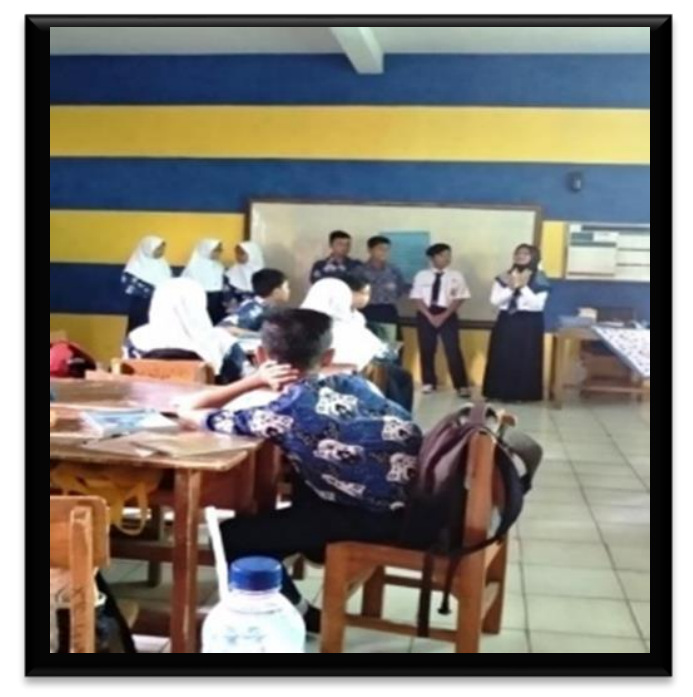

Gambar 5. Siswa Mempresentasikan hasil diskusi dengan kelompok dan pasangannnya.

\section{Langkah terakhir yang dilakukan peneliti menggunakan model pembelajaran Cooperative Script yaitu merumuskan kesimpulan bersama siswa. Pada pertemuan pertama dan kedua siswa ketika membuat kesimpulan masih banyak}

yang terdiam apa yang harus dikatakan dan diungkapkan. Artinya pada pertemuan pertama masih harus disimpulkan sendiri oleh peneliti meski sudah diberi beberapa petunjuk. Pada pertemuan selanjutnya siswa berlomba-lomba mengemukakan pendapat tentang kesimpulan apa yang diperoleh pada pertemuan tersebut.

Berdasarkan hasil observasi, karena siswa terbiasa dengan pembelajaran yang diberikan di sekolah yaitu pembelajaran yang kurang berinovasi maka hasil observasi kecakapan siswa masih tergolong sangat rendah dan dalam setiap pembelajarannya jarang sekali diberikan permasalahan kecakapan akademik siswa. Untuk hasil tes juga pada setiap menunjukkan peningkatan yang cukup signifikan setelah pembelajaran menggunakan model Cooperative Script. Pada pertemuan ketiga ini nilai siswa sudah mulai menunjukkan hasil yang baik dibandingkan dengan pertemuan pertama, dimana siswa bingung langkah apa yang harus dilakukan ketika menyelesaikan soal kecakapan akademik. Pada pertemuan pertama siswa langsung melakukan perhitungan dengan seadanya. Yang hasilnya menunjukkan bahwa sebagian besar peserta didik masih banyak yang belum paham maksud dari permasalahan tersebut. Akan tetapi juga terdapat beberapa siswa pada kecakapan akademiknya sudah ada yang masuk ke dalam kategori tinggi.

Faktor yang menyebabkan kecakapan akademik siswa termasuk kategori tinggi adanya kontribusi penggunaan model

Mosharafa: Jurnal Pendidikan Matematika Volume 8, Nomor 1, Januari 2019 Copyright $\odot 2019$ Mosharafa: Jurnal Pendidikan Matematika 
Cooperative Script dalam pembelajaran dimana siswa diberikan peran sebagai pembicara dan juga sebagai pendengar atau saling bertukar peran. Sehingga siswa mendapat penguatan dalam materi yang diajarkan. Menurut siswa, dengan menggunakan model Cooperative Script, siswa sebaga pembicara membacakan ringkasan dengan lengkap terhadap materi yang diajarkan. Pada tahap ini, siswa sebagai pembicara harus sudah menelaah, memahami, dan mampu menarik kesimpulan dalam setiap proses model ini. Ketika siswa mendiskusikan siswa juga harus mampu memberikan ide-ide pokok yang kurang lengkap. Membantu mengingat ide-ide pokok dengan menghubungkan materi sebelumnya.

\section{Penutup}

Berdasarkan hasil penelitian dan pembahasan diperoleh kesimpulan bahwa secara umum hasil observasi kecakapan akademik siswa menunjukkan bahwa dalam kategori sangat kurang dengan ratarata 38.5, akan tetapi setelah pembelajarannya menggunakan model Cooperative Script hasil tes kecakapan akademik mengalami peingkatan yaitu menunjukkan kategori sangat tinggi dengan rata-rata 86.73. Berdasarkan kesimpulan diatas maka hendaknya guru berani mencoba menerapkan metode mengajar bervariasi dalam pembalajaran dalam meningkatkan berbagai kemampuan akademik siswa.

\section{Daftar Pustaka}

Afriansyah, E. A. (2017). Problem Posing sebagai Kemampuan Matematis. Mosharafa: Jurnal Pendidikan Matematika, 6(1), 163-180.

Anwar (2006). Pendidikan Kecakapan Hidup. Bandung: Alfabeta

Depdiknas (2003). Konsep Pendidikan Kecakapan Hidup. Jakarta: Depdiknas

Noor, J dan Norlaila, N (2014). Kemamapuan Pemecahan Masalah Matematis Siswa dalam Pembelajaran Matematika Menggunakan Model Cooperative Script, Jurnal Pendidikan Matematika Universitas Lambung Mangkurat. Vol 2, No 2 (2014).

Saudagar, Fachrudin dan Idris, Ali (2009). Pengembangan Profesionalitas Guru. Jakarta; GP press Suprijono, A. (2010). Cooperative learning teori dan aplikasi PAIKEM. Yogyakarta: Pustaka Pelajar. Slavin (2006). Accommoding Student

Diversity in Reading and Writing Instruction, Cooporative Learning Aproach, Journal of Technology Education 18 (1): 52-55.

Sulastri, S. \& Haq, C. N. (2013). Perbedaan Kemampuan Komunikasi Matematik Siswa antara yang Mendapatkan Model Pembelajaran Jigsaw dan Cooperative Script. Mosharafa: Jurnal Pendidikan Matematika, 2(2), 111122.

Zanthy, L. S. (2018). Kontribusi Resiliensi Matematis terhadap Kemampuan Akademik Mahasiswa pada Mata Kuliah Statistika Matematika. Mosharafa: Jurnal Pendidikan Matematika, 7(1), 85-94. 


\section{Riwayat Hidup PENULIS}

\section{Linda Herawati, M.Pd.}

Lahir di Kediri, 27 Oktober 1981. Studi S1 Pendidikan Matematika Universitas Siliwangi, Kota Tasikmalaya, lulus tahun 2004: S2 Pendidikan Matematika Universitas Terbuka, UPBJJ Bandung, lulus tahun 2014.

\section{Elis Nurhayati, M.Pd.}

Lahir di Tasikmalaya, 24 September 1981. Studi S1 Pendidikan Matematika Universitas Siliwangi, Kota Tasikmalaya, lulus tahun 2003: S2 Pendidikan Matematika Universitas Pendidikan Indonesia, Bandung, lulus tahun 2016. 